\section{Filosofi og psykiatri}

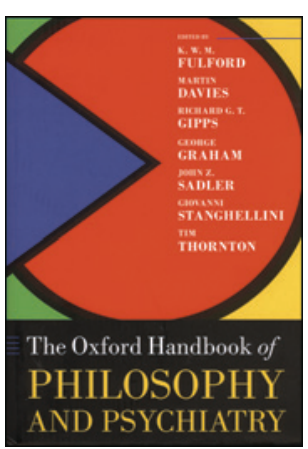

Bill Fulford, Martin Davies,

Richard Gipps et al, red.

The Oxford handbook of philosophy and psychiatry

1322 s, tab, ill. Oxford: Oxford University

Press, 2013. Pris GBP 95

ISBN 978-0-19-957956-3

Dette omfattende verket har sju redaktører og vel 80 medarbeidere, de fleste filosofer. Knapt en firedel er psykiatere og psykologer. Flertallet er britiske og amerikanske, og det er ingen fra Norge. En rekke av forfatterne har bakgrunn fra empirisk forskning. Boken er skrevet hovedsakelig for filosofer, men teoretisk interesserte psykiatere og psykologer vil også finne verket stimulerende.

Boken har åtte store hoveddeler. Å gi et kort referat av innholdet i dette verket er vanskelig. For her drøfter ikke bare forfatterne filosofiske spørsmål knyttet til etiologi, diagnostikk, prognose og behandling av psykiske lidelser, men reliabilitet og validitet, identitet og verdier. De er ofte innom Sigmund Freuds psykoanalyse og filosofer som Kierkegaard, Nietzsche, Heidegger, Sartre, Wittgenstein, Merleau-Ponty og selvsagt Karl Jaspers, som også var psykiater.

Den frie vilje dukker ofte opp i diskusjonen. De fleste av oss opplever å ha en fri vilje, men er det en illusjon? Det er vel egentlig bare to grupper av mennesker som hevder at deres vilje ikke er fri: schizofrene, som mener at deres tanker er kontrollert og manipulert av andre, og filosofer som tror på determinismen.

I den historiske delen omtaler forfatterne blant annet den tyske psykiateren Wilhelm Griesinger som på midten av 1800-tallet gikk inn for en radikal somatisk psykiatri, videre Jaspers' Allgemeine Psychopathologie fra 1913. I begrepsdelen drøfter de hva en psykisk lidelse er. I delen om interpersonelle forhold burde diskusjonen om empati være av særlig interesse for psykiatere og psykologer. I delen om behandling og omsorg er kapitlet om placebo i psykiatri og psykoterapi meget instruktivt, og tar nok livet av en del myter som kanskje mange leger også tror på.

I ett kapittel diskuterer Rachel Cooper det problematiske ved psykiatriske klassifikasjoner. Mens kjemiske inndelinger er presise, er de psykiatriske uklare. Mens kjemiske inndelinger er objektive, er psykiatriske verdiladede. Det trekkes en analogi mellom begrepene mental forstyrrelse og ugress. Ugress er ikke en vitenskapelig relevant kategori, det er ikke noe iboende dysfunksjonelt ved ugress, ugress er bare planter vi ikke liker fordi de skjemmer vår hage. Ugress er altså ikke en teknisk, økologisk term. Kommer mental lidelse i samme kategori?

Gjennom de siste årtiene har man sett en økende interesse for personlighetsforstyrrelser, både klinisk og forskningsmessig. I tidlig romersk-katolsk middelalder ble mange laster klassifisert som synder. De sju dødssyndene var fråtsing, lyst, grådighet, vrede, latskap, hovmod og misunnelse, som i dag er gått inn i moderne psykiatrisk klassifikasjon. I DSM-V er fråtsing blitt «binge eating disorder», lyst hyperseksuell forstyrrelse, grådighet obsessiv-kompulsiv forstyrrelse og hovmod og misunnelse narsissistisk forstyrrelse. Siden dette er en amerikansk klassifikasjon kan man med god grunn spørre hvorfor én last er kommet med og ikke en annen. Hvorfor ikke klassifisere tyveri, drap eller for den saks skyld rasisme og løgn som en mental lidelse?

Forfatterne er saklige i sin kritiske diskusjon og imponerende kunnskapsrike når det gjelder nyere psykiatrisk forskning. Med kledelig moderasjon lover de ingen nye «grand theories», og heller ikke gjør de forsøk på å forklare hva bevissthet er, eller løse problemet med den frie vilje. Ved slutten av det århundret vi er inne i, vil nok de store spørsmålene om sinn og hjerne, om frihet og determinisme fortsatt bestå.

Dette er en høyst leseverdig bok som imidlertid ikke kan fordøyes over natten. En del av stoffet er tungt, og anmelderen må vedgå at han kanskje ikke er kvalifisert til å gi dette omfattende arbeidet en adekvat nok kritikk.

\section{Einar Kringlen \\ Psykiatrisk institutt, Vinderen \\ Universitetet i Oslo}

\section{Forenklet og praktisk om idrett og ernæring}

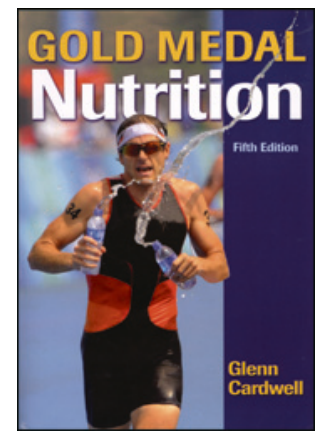

Glenn Cardwell

Gold medal nutrition

5. utg. 256 s, tab, ill. Leeds: Human Kinetics,

2013. Pris GBP 17

ISBN 978-1-4504-1120-2

Gold medal nutrition er en lærebok i idrettsernæring der forfatteren ønsker å formidle kunnskapen på en enkel og praktisk måte. Tittelen refererer til toppidrettsutøvere som målgruppe, men etter å ha lest boken tenker jeg at den i stor grad også treffer mosjonistene. Cardwell er ernæringsfysiolog fra Australia, og de praktiske tipsene er i hovedsak vinklet mot australske matvarer.

Første del er en systematisk gjennomgang av makro- og mikronæringsstoffer, mens forfatteren i den andre delen tar for seg mer spesifikke problemstillinger i idrettsernæring. Alle kapitlene inneholder mange lange tabeller med matvarer, praktiske tips og råd og avsluttes med et sammendrag av de viktigste punktene. Den første delen er godt skrevet, og forfatteren klarer å oversette vitenskap til veldig enkle forklaringer, mens den andre delen er så praktisk og forenklet at det kan grense til det kjedsommelige. Det er en utfordring å legge opp en bokstruktur i idrettsernæring uten for mange gjentakelser, da de ulike makronæringsstoffene er aktuelle i alle kapitler som omhandler ernæring i forhold til trening. Cardwell har valgt en oppbygging som fører til en del gjentakelser, spesielt i den andre delen, og språket er veldig muntlig: «Du er helt gal hvis du kutter ned på karbohydratene!»

Som konklusjon vil jeg si at boken egner seg godt for unge idrettsutøvere og mosjonister som ikke har noen forkunnskaper om ernæring og trening, og som ikke har behov for den vitenskapelige utredningen. Sammenliknet med andre engelskspråklige bøker om idrettsernæring er dette en billig og praktisk bok for denne målgruppen. For en leser med noe bakgrunn i idrettsfysiologi og ernæring, eller den erfarne toppidrettsutøveren, vil boken kunne fremstå som forenklet og til tider litt kjedelig.

Ina Garthe

Olympiatoppen 